\title{
Effects of predators on growth, mortality and abundance of a juvenile reef-fish: evidence from manipulations of predator and prey abundance
}

\author{
S. D. Connell* \\ School of Biological Sciences A08, University of Sydney, New South Wales 2006, Australia
}

\begin{abstract}
Studies of open populations, in which offspring are dispersed away from their natal site, often emphasise density-independent processes, namely stochastic variation in the input of newly arrived young (recruitment). Studies of closed populations, in which offspring remain close to their natal site, emphasise the role of density-dependence, particularly through competition and predation. The usefulness of this dichotomy was tested on spiny chromis Acanthochromis polyacanthus, which is one of the few marine fish that lack a pelagic larval phase and is thought to be the archetypal species for closed population status among reef-fishes. Experimental manipulations showed that juvenile $A$. polyacanthus suftered lower rates of mortality in locations where large predatory fish were excluded. The magnitude of differences in mortality between treatments (cages and open plots) matched natural differences in mortality between locations representing low and high numbers of predators, suggesting that large predatory fish were a primary source of juvenile mortality. Growth did not increase when prey and predator abundances were reduced. This finding rejected 2 models: that growth was reduced in large schools and these slower growing individuals suffered greater rates of predation; and that intraspecific competition occurred. Growth of prey increased when released from predation pressure, a process not previously considered in studies of growth in reef-fish. The repression of growth in response to predation pressure indicates that predators may have a more far-reaching effect on demography of reef-fish than previously thought. Predation was density-dependent in that juveniles in larger schools suffered greater rates of mortality in the presence of predators but not in their absence. Predation appeared to limit the upper size of schools, but this did not eliminate a linear relationship between input and subsequent abundance. Hence, density-dependent predation was weak and large fluctuations in recruitment (births) persisted and contributed importantly to fluctuation in prey density. These results support the model that when density-dependent mortality is weak, both input and subsequent mortality will be important limiting factors. Consequently, this study questions the assumption that variation in predation and competition has greater consequences for closed populations.
\end{abstract}

KEY WORDS: Reef-fish Predation Mortality Open populations - Growth Experiment

\section{INTRODUCTION}

Early studies of ecology focused on 'closed' populations (sensu Caswell 1978) in which offspring remain close to their natal site. Historically, ideas of densitydependent regulation have arisen from the study of closed populations (e.g. MacArthur et al. 1966, Cody

\footnotetext{
- Address for correspondence: Centre for Research on Ecological Impacts of Coastal Cities, Marine Ecology Laboratories A11, University of Sydney, New South Wales 2006, Australia.E-mail: sconnell@bio.usyd.edu.au
}

1968). However, many populations are 'open'. For example, the majority of marine fish have a dispersive phase in which sedentary adults produce larvae that disperse from their natal reefs to new reefs (Doherty 1991). Most studies of open populations of reef-fish have emphasised the role of stochastic variation in the input of new individuals (recruitment); an increase in recruitment is thought to lead to an increase in population size (for reviews see Doherty \& Williams 1988, Doherty 1991, Booth \& Brosnan 1995). The implicit assumption is that the rate of demographic processes (e.g. mortality) do not alter patterns of recruitment. 
The western Pacific pomacentrid Acanthochromis polyacanthus (spiny chromis) is the only well documented reef-fish that lacks a dispersive larval phase (Thresher 1983a, 1984) and as such has been argued to be the archetypal candidate for closed population status among reef-fishes (Booth \& Brosnan 1995). A. polyacanthus do not disperse into the water column as eggs or after hatching from eggs, but remain within their parents' territory for a number of days (Thresher 1984). Such direct development results in extremely limited dispersal of new young. Therefore, if the closed/open population-density-dependent/independent dichotomy is useful, I predict density-dependence in this reef-fish.

Although many marine organisms by-pass the planktonic larval period, most have a planktonic phase where dispersal varies from a few meters (Olson 1985) to thousands of kilometres (Scheltema \& Williams 1983). Contrary to the current paradigm, not all coral reef-fishes with pelagic larvae live in open populations. In some atoll lagoons, some taxa have predominantly closed populations in which they complete their life-cycles (Leis 1994). Most studies of reef-fish focus on solitary species with widely dispersed young, hence insights into species of a very different nature, such as Acanthochromis polyacanthus, may offer new perceptions of the more intensely studied species and a greater understanding of population dynamics of reeffish in general. Indeed, comparisons of life-history traits of species with contradictory dynamics have provided clues about the nature of differences in population dynamics of other systems (e.g. Cappuccino \& Price 1995) for which dispersal distance has been hypothesised to be an important trait (Hunter 1995).

Mortality is the most direct way population abundance may be modified. Predation, particularly by large fish, is a major source of mortality in juvenile reef-fish (Shulman \& Ogden 1987, Hixon \& Beets 1993, Carr \& Hixon 1995) and this is thought to be the case for juvenile Acanthochromis polyacanthus. These juveniles suffer high rates of mortality which can be correlated to the abundance of large predatory fish (Connell 1996) Although large predatory fish make up a large proportion of coral reef-fish assemblages (Williams \& Hatcher 1983), there are many other predators (Hixon 1991) and sources of mortality in fish, e.g. parasitism (Minchella \& Scott 1991), disease (Schmale 1991) and cannibalism (Nakazono 1993). Hence, explanatory statements about the causes of mortality may have little predictive power until there is a greater understanding of the contribution of alternate sources of mortality.

New evidence suggests that predation may play a larger role in open populations of reef-fish than previously thought. Resident predators can alter the density and size structure of Carribbean reef-fishes shortly after settlement (Shulman \& Ogden 1987, Hixon \& Beets 1993) and may also affect the structure of these reef-fish communities by altering the relative abundances of prey established at settlement (Carr \& Hixon 1995). Reduced predation pressure at One Tree Reef on the Great Barrier Reef resulted in increased abundance of prey (Doherty \& Sale 1985) and alteration of patterns of recruitment (Caley 1993). Moreover, these studies suggest that the effect of predation on patterns of prey abundance depends largely on the modification by predators of peaks in abundance of new juveniles (Caley et al. 1996, Steele 1997). Despite this evidence, debate centres on the notion that variation in recruitment to open populations swamps any effect due to predation (Doherty 1991, Doherty \& Fowler 1994)

Using a closed population of reef-fish, Acanthochromis polyacanthus, this paper presents the results of field experiments designed to (1) test whether large predatory fish were the primary source of mortality observed in 2 habitats, (2) determine whether schoolsize affects per capita rates of mortality under different regimes of predator pressure, and (3) assess the relative contributions of recruitment and predation in structuring patterns of juvenile abundance.

\section{METHODS}

The prey species and links to predators. The work was done between October 1991 and December 1993 in the largest lagoon of One Tree Reef (233' $\mathrm{S}$, $\left.152^{\circ} 06^{\prime} \mathrm{E}\right)$, a lagoonal platform reef in the CapricornBunker group, Great Barrier Reef, Australia (described in Jones 1987). The prey examined, juvenile Acanthochromis polyacanthus (Pomacentridae), are known to be consumed by the most abundant serranid, Plectropomus leopardus (Kingsford 1992), and a Iutjanid, Lutjanus carponatatus (S. Connell pers. obs.), within the main lagoon of One Tree Reef. Other common large predatory fish (>200 $\mathrm{mm}$ total length, IL) have also been documented to consume fish within the main lagoon of One Tree Reef (Connell 1998).

Adult Acanthochromis polyacanthus are generally territorial and form stable heterosexual. pairs. Females lay eggs in crevices (Thresher 1985a, Nakazano 1993), producing up to 300 fry at hatching (Thresher 1983a). Hereafter I refer to the fry as juveniles (sensu Leis \& Rennis 1983, Thresher 1983a, b, 1984). These freeswimming juveniles form a small school that is defended by both parents until they reach an age of approximately $30 \mathrm{~d}$ and a total length of approximately $20 \mathrm{~mm}$ (Thresher 1983a). During this time, juveniles live within their parents' territories and are 
protected by their parents from the attack of piscivores (Nakazano 1993). These juveniles are unlikely to survive in the absence of their parents because if one or both are removed from the school, disappearance of the school through predation is almost certain (Thresher 1985b, Nakazano 1993). Hence, the loss of small individuals ( $<20 \mathrm{~mm}$ TL) from within a school is more likely to represent mortality than emigration. The current study focused on smaller individuals $(<18 \mathrm{~mm}$ TL) to ensure that estimates of mortality were not confounded by emigration.

Expt I: Is predation by large predatory fish the primary cause of prey mortality? This experiment tested the hypothesis that large predatory fish (>200 mm TL) were the main source of Acanthochromis polyacanthus mortality between locations with naturally high and low densities of predators. I observed natural patterns of prey mortality and predator density on 2 types of natural reef: (1) continuous reef at the margins of the lagoon had high densities of predators; and (2) natural patch reefs of approximately $10 \times 20 \mathrm{~m}$, located within the centre of the lagoon, had low density of predators.

The density of predators was estimated using underwater counts along five $25 \times 5 \mathrm{~m}$ transects at 6 sites within each habitat (Connell \& Kingsford 1998). Survivorship of juvenile Acanthochromis polyacanthus was estimated from hatching to $18 \mathrm{~mm}$ TL at 3 sites within each habitat (see Connell 1996), and found to be lower on continuous reef where there were greater numbers of predators (Table 1). Predator density on continuous reef was consistently greater than on patch reef for 5 temporal scales (time of day, days, weeks, months and years) throughout the current study (Connell \& Kingsford 1998). These results provided necessary information for the design of experiments in this study, including the potential 'effect-size' of predation. 'Effect-size' (sensu Cohen 1988) is a formal term used in power analysis to describe the size of treatment effects that are expected or observed. Predation pressure was manipulated with exclusion cages in 1992 (see below: 'Manipulation of predator abundance') and located on continuous reef between October and December. Careful attention was paid to replication (see below' 'Replication and statistical evaluations') and the spatial placement of replicates (Connell 1997).

Expt II: Does school-size of prey affect (1) growth and (2) rates of mortality? 'This experiment tested 3 hypotheses: (1) that predation is density-dependent, hence the rate of mortality increases with prey abundance in treatments of high predation risk; (2) that growth of prey is negatively related to school-size, indicating intraspecific competition; and (3) that intraspecific competition and predation interact such that growth is reduced in large schools and these slower growing individuals suffer greater rates of mortality.
The experiment was based on the same caging treatments as in Expt I, plus an additional treatment in which prey density was manipulated prior to cage construction. Abundances of both predator and prey were manipulated in a 2-way design between October and December 1993. Schools were manipulated to be small (ranging from 13 to 65 individuals) or large (ranging from 85 to 170 individuals). These 2 ranges in abundance reflect the overall range of natural variability in initial size of schools $(20$ to 170 individuals per school) and correspond to abundance-related differences in prey behaviour towards predators (Thresher 1985a). Thresher (1985a) observed that small schools $(<75$ individuals) tended to form a defensive 'sphere' when faced with the threat of predation, whereas this behaviour occurred infrequently among large schools (>75 individuals)

For consideration of 'density-dependent' and 'density-independent' processes, abundance is assumed to represent density, as is typical for insects on leaves (e.g. Conner \& Beck 1993). Although school area was not directly measured, these schools are discrete units of approximately the same area. Density-dependence is defined as the dependence of per capita mortality on

Table 1. Acanthochromis polyacanthus. Patterns of predator abundance (per $125 \mathrm{~m}^{2} \pm \mathrm{SE}$ ) and prey survivorship between the edge and centre of the main lagoon at One Tree Reef during 1991-1993. Predator abundance is given for the most abundance families of large predatory fish ( $>200 \mathrm{~mm}$ TL) sampled in November of each year ( $\mathrm{n}=5$ transects at each of 6 sites). A. polyacanthus survivorship is given per school ( $\mathrm{n}=$ 30 schools) from hatching to $18 \mathrm{~mm}$ TL. The following species contributed to these data: Lutjanidae (Lutjanus carponatatus, Lutjanus russelli, Lutjanus fulviflamma, Lutjanus monostigma, Lutjanus adetii, Lutjanus bohar); Serranidae (Plectropomus leopardus, Epinephelus quoyanus, Epinephelus cyanopodus, Cephalopholis miniata, Cephalopholis argus, Cromileptus altivelis); Labridae (Cheilinus diagrammus, Cheilinus fasciatus, Cheilinus trilobatus)

\begin{tabular}{|lrr|}
\hline & \multicolumn{2}{c|}{ Habität type } \\
& Continuous reet & Patch reef \\
\hline 1991 predator abundance & & \\
Lutjanidae (snapper) & $6.9 \pm 1.3$ & $0.9 \pm 0.2$ \\
Serranidae (grouper) & $3.6 \pm 0.7$ & $0.3 \pm 0.2$ \\
Labridae (wrasse) & $0.6 \pm 0.2$ & $0.4 \pm 0.1$ \\
Prey survivorship (\%) & $60.4 \pm 3.9$ & $91.0 \pm 1.8$ \\
1992 predator abundance & & \\
Lutjanidae (snapper) & $6.1 \pm 1.2$ & $0.4 \pm 0.1$ \\
Serranidae (grouper) & $1.0 \pm 0.2$ & $0.1 \pm 0.1$ \\
Labridae (wrasse) & $0.4 \pm 0.1$ & $0.0 \pm 0.0$ \\
Prey survivorship (\%) & $68.6 \pm 3.2$ & $82.6 \pm 2.2$ \\
1993 predator abundance & & \\
Lutjanidae (snapper) & $8.9 \pm 1.7$ & $0.6 \pm 0.2$ \\
Serranidae (grouper) & $1.7 \pm 0.3$ & $0.1 \pm 0.1$ \\
Labridae (wrasse) & $0.2 \pm 0.1$ & $0.1 \pm 0.1$ \\
Prey survivorship (\%) & $68.2 \pm 3.8$ & $87.1 \pm 2.9$ \\
& & \\
\hline
\end{tabular}


population density, similar to Murdoch \& Walde (1989). The number and rational for replication of treatments is described below ('Replication and statistical evaluations'). All replicates were haphazardly located among 3 locations on continuous reef where predator abundance was high.

Monitoring abundance and mortality of prey. Adult pairs of Acanthochromis polyacanthus without juveniles were visited every second day to determine whether hatching had occurred. The number and mean total length of new juveniles observed with an adult pair within a $48 \mathrm{~h}$ period defined recruitment. Hatching within a batch of eggs appeared to occur simultaneously, but hatching among batches occurred between mid October and at least late November. Mortality rates were based on the loss rate of a cohort of individuals hatched from a single batch, and individual batches or schools could be followed through time because they continuously occupied a discrete area of reef. Mortality was calculated using the percentage of individuals lost between hatching (generally $6 \mathrm{~mm}$ TL) and mean total length of $18 \mathrm{~mm}$, after which some individuals were observed to pass briefly outside their cages. Errors in counting and length estimation in the field were quantified by comparing estimates of abundance and length with collections of the same fish (Connell 1996). Because these errors did not alter the results, uncorrected data are presented.

Manipulation of predator abundance. Three treatments manipulating predator abundance included: (1) exclusion cages (full cages) which allowed access of small fishes but excluded large fishes (>200 mm TL); (2) cage controls (partial cages) that allowed access of all fish while controlling for the presence of the cage; and (3) unmanipulated controls (open plots) that had no structure and allowed access of all fish. Four steel stakes ( $3.2 \mathrm{~m}$ length) were driven approximately $1 \mathrm{~m}$ into the substratum and acted as corner posts for a roughly square cage enclosing a surface area of $3.6 \pm 0.3 \mathrm{~m}^{2}$ Galvanised wire mesh (with a mesh size of $50 \mathrm{~mm}$ ) was fastened to the stakes to create a top and 4 sides. Partial cages were of similar configuration to full cages, except that only half of each side was covered in mesh (see Connell 1997). Full and partial cages were constructed around individual Acanthochromis polyacanthus schools and their parents and completed before dark on the day hatching was first detected. To determine whether cage construction influenced immediate juvenile survival, school size was counted immediately before and after construction. No immediate losses were detected.

Full cages used in this study were effective in excluding large predatory fish. Hence, losses within cages were considered to be due to any source of mortality, except predation by large predatory fish (>200 mm TL) with a high body profile. Cages were accessible to small invertebrates (e.g. Stomatopoda), small fish (e.g Pseudochromidae, Synodontidae), elongate predators (e.g. Muraenidae, Synodontidae, Fistularidae) and juveniles of the large predatory fish $(<200 \mathrm{~mm}$ TL) (e.g. Serranidae, Scorpaenidae, Lutjanidae).

The literature was reviewed for major artefacts associated with caging fish from hard substrata, and special attention was given to these artefacts in planning and interpreting the experiments (see Connell 1997). In cases where artefacts could not be minimised or eliminated from the experimental design, controls were augmented with additional data to determine the importance of these artefacts. It was concluded that caging artefacts were minimal, and that the experimental effects of excluding large predatory fish could be interpreted (Connell 1997).

Replication and statistical evaluations. The level of replication for each experiment was based on the potential effect-size of predation observed in the previous year. For Expt I, observations of mortality in the previous year (1991) indicated that survivorship was $30 \%$ greater in locations containing fewer large predatory fish (patch vs continuous reef) (Table 1). The number of replicates needed to detect this effect-size was determined using a statistical procedure that calculates sample size and power for a 1-factor ANOVA (Underwood 1981). This calculation indicated that 6 replicates per treatment were required to detect a $30 \%$ difference (power $=0.89$ at $\alpha=0.05$ ), hence 6 replicate treatments were used in Expt I.

The level of replication for Expt II was calculated to detect at least a $14 \%$ difference in survival, that is, the difference in magnitude of mortality found between full cage and open plot treatments in Expt I. The calculation determined that 12 replicates per treatment (open plots, full and partial cages) would be needed to have a $95 \%$ chance of detecting a $14 \%$ difference among the 3 treatments (power $=0.80$ at $\alpha=0.05$ ). Hence 12 replicate treatments were used for Expt II

All data were analysed with ANOVA. Data were tested for homogeneity with Cochran's $C$ test and transformation of data followed procedures suggested by Underwood (1981). Percentage data were transformed using arc-sine square root; abundance data did not require transformation.

The use of size-related mortality. In this study survivorship was estimated by the size, not age, of the individual, because size may be more important in determining life-history characteristics for fishes, as it is for many other organisms with indeterminate growth rates (see Kirkpatrick 1984). It is often suggested that growth rates in fish may influence mortality, especially if mortality is size-dependent (e.g Doherty \& Sale 1985). Moreover, growth rates of fish are often the most 
sensitive demographic parameter to changes in environmental conditions (review Jones 1991) and can identify the important life-stages for which members of a population are likely to undergo profound changes in their abundance. In this study, the response of prey to predation pressure was strongly related to growth.

\section{RESULTS}

Expt I: Are large predatory fish the primary cause of prey mortality? There was a trend for survival to be enhanced in full cages for both Expt I and II (Fig. 1). This phenomenon in itself is not surprising given that the exclusion of piscivores, which by definition eat fish, is likely to affect prey mortality. Importantly, the difference in survivorship between full cages (no large predators) and open plots (large numbers of predators) was similar to the difference in survival between habitats containing naturally high or low numbers of these same predators (Table 2). This observation provided strong evidence that large predatory fish were primarily responsible for the difference in mortality observed between continuous and patch reef.

Interpretation of statistical results for Expt I (1992) was equivocal. Although all treatments started with similar numbers of recruits (ANOVA: $F_{2.2}=0.01, p>$ 0.50 ) and there was a trend for mortality to be greater among open plots (Fig. 1), no differences were detected in survival (ANOVA: $F_{2,2}=1.92, p>0.10$ ) and subsequent numbers of juveniles (ANOVA: $F_{2,2}=0.36$, $\mathrm{p}>0.50$ ). Post-hoc power analysis, however, indicated that the experiment may not have been powerful enough to detect the effects of the treatments on survival (power $=0.42$ ). This result may have occurred because the differences between cages and open plots were less than expected. Although power analysis based on preliminary (1991) estimates of the predation effect $(30 \%)$ was used to establish replicate number, such an effort can only be used as a rough guideline since effect magnitudes could be less (reduced to $14 \%$ in this study) or more than the preliminary estimates.

The apparent importance of predation but equivocal statistical result motivated Expt II (1993). This second experiment not only retested the importance of predation using the revised effect-size of $14 \%$ (1992), but it also assessed whether mortality rates associated with predation would respond to variation in prey abundance

Expt II: Does predation cause density-dependent mortality? If mortality is caused by density-dependent predation, per capita mortality should increase with increasing school-size in the presence of predators, but show no trend in the absence of predators. The data show a positive relationship between mortality and (a) Experiment I

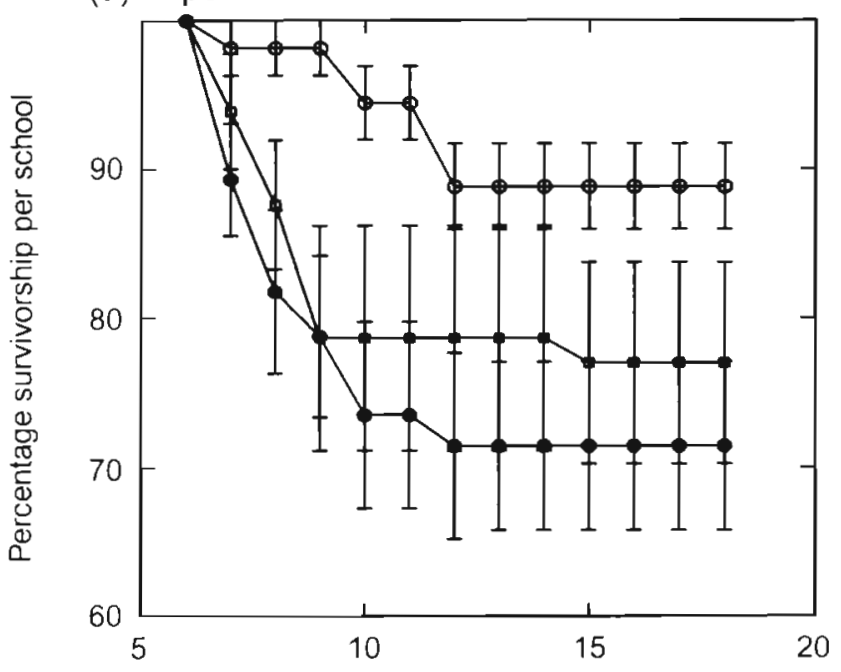

(b) Experiment II

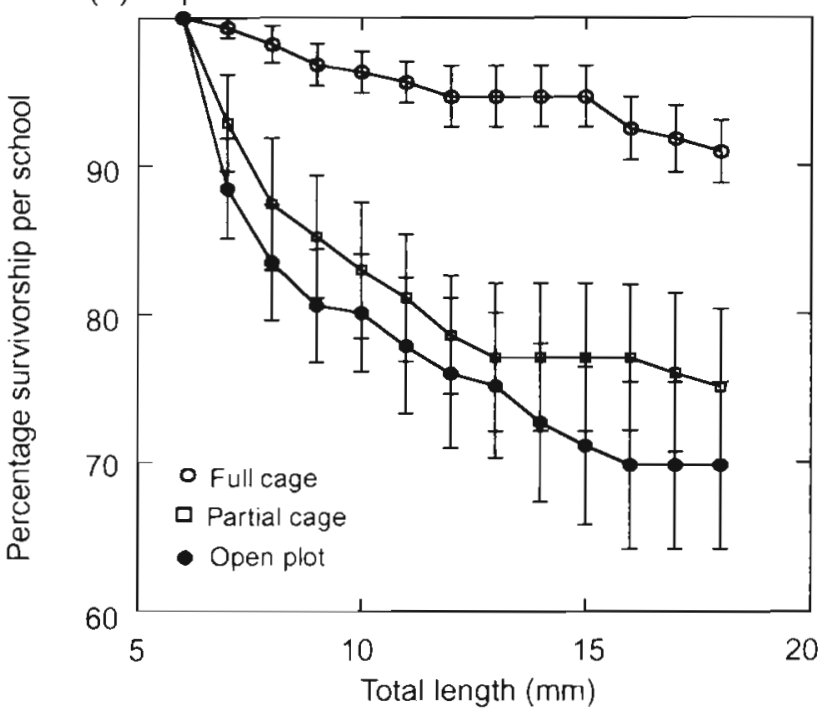

Fig. 1 Acanthochromis polyacanthus. Mean percentage survival $( \pm \mathrm{SE}$ ) per school among the 3 caging treatments versus total length of juvenile individuals. Shown are the results from (a) Expt I $(n=6)$ and (b) Expt II $(n=12)$

school-size in the presence of predators (Fig. 2a: Spearman's rank correlation cofficient $=0.39, \mathrm{n}=24$, $\mathrm{p}<0.05$ for 1-tailed test), but not in their absence (Fig. 2a: Spearman's rank correlation cofficient $=0.18$, $\mathrm{n}=12, \mathrm{p}>0.05$ for 1 -tailed test). Although this suggests that mortality was structured by density-dependent predation, this relationship was weak (Fig. 2a) and ANCOVA did not detect differences in school-sizerelated mortality between treatments with and without predators (interaction for the slopes: $F_{1,32}=0.75, \mathrm{p}>$ $0.25)$.

Although small schools ( $<75$ individuals) are more defensive towards attacks from predators (Thresher 
(a)

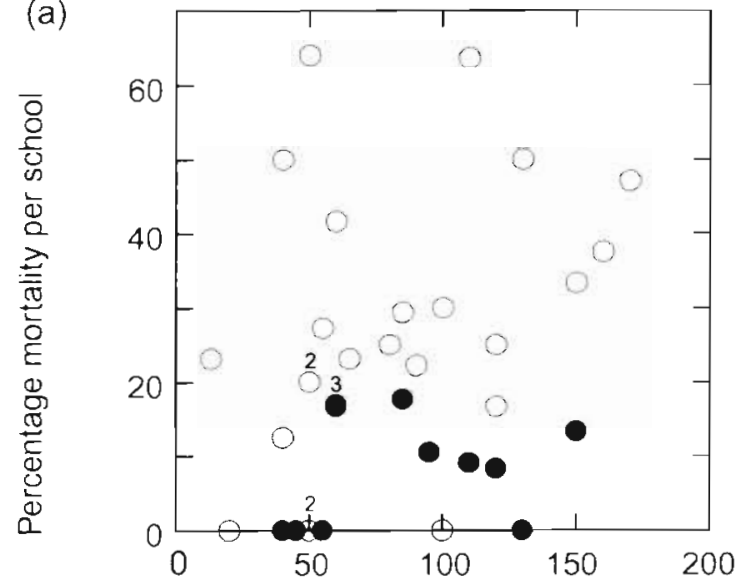

Initial number of juveniles per school

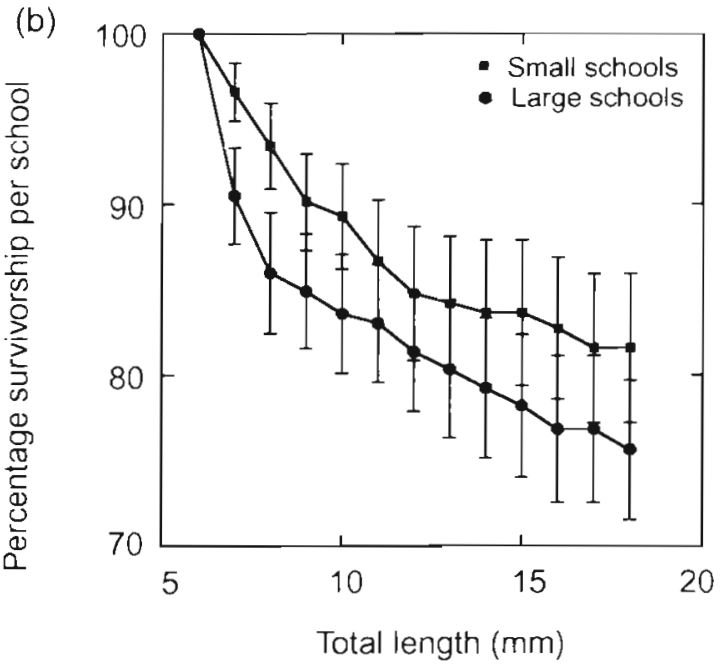

1985a) this behaviour did not greatly affect the rate of mortality (Fig. 2b). Similar proportions of juveniles were lost from small and large schools (Fig. 3). Juvenile survivorship was significantly greater in full cages than in partial cages and open plots (Fig. 1b, Table 3a; SNK test, full $>$ open $=$ partial $)$.

Final and initial patterns of abundance were decoupled among cage treatments but not between density treatments. Between density treatments, large schools remained larger than small schools (cf. Fig. 3a, b, Table $3 b, c)$. Among cage treatments, final abundance followed a simple pattern (Table 3c; SNK test, full = open > partial), whereas initial abundance showed an interaction between cage and density treatments (Table 3b; SNK test, open $>$ cage $>$ partial among large schools and open = cage $=$ partial among small schools). This indicates that predation can modify small variation in recruitment (Fig. 3a, b: compare rank abundance for large schools), but not the largest variation in recruitment (Fig. 3a, b: compare rank abundance between small and large schools).

A positive correlation between input and subsequent abundance has been used as evidence for recruitment limitation (Doherty \& Fowler 1994). While there was a significant positive correlation between initial and remaining number of prey in both the presence (Spear-

Fig. 2. Acanthochromis polyacanthus. Expt II. Effect of schoolsize on (a) mortality of juveniles among treatments with predators $(O=$ open plots and partial cages, $n=24)$ and without predators $(- \text { full cages, } n=12)_{\text {i }}$ and (b) mean percentage survival ( $\pm \mathrm{SE}$ ) per small and large school among all treatments $(n=18)$. Numbers above symbols represent repeated (superimposed) counts

Table 2. Acanthochromis polyacanthus. Comparison of natural and experimental survivorship (between hatching and 18 mm TL) among locations and treatments of high and low predation pressure. Predation pressure is mferred from the density of large predatory fish that was (1) high on continuous reef and open plots, (2) low on patch reefs, and (3) zero in full cages. $\vec{x}=$ mean percent survivorship per school., $s=1$ standard deviation of the mean

\begin{tabular}{|c|c|c|}
\hline & Natural survivorship & Experimental survivorship \\
\hline \multicolumn{3}{|l|}{ (a) Experiment I } \\
\hline Predation pressure low & $\begin{array}{c}\text { Patch reef } \\
\bar{x}=82.6, s=12.2, \mathrm{n}=30\end{array}$ & $\begin{array}{c}\text { Full cage } \\
\bar{x}=87.7, s=7.6, \mathrm{n}=6\end{array}$ \\
\hline Predation pressure high & $\begin{array}{c}\text { Continuous reef } \\
\bar{x}=68.6, s=17.3, n=30\end{array}$ & $\begin{array}{c}\text { Open plot } \\
\bar{X}=71.4, s=13.8, n=6\end{array}$ \\
\hline Likely effect due to predators & Patch - Continuous $=14.0$ & Full - Open $=16.3$ \\
\hline \multicolumn{3}{|l|}{ (b) Experiment II } \\
\hline Predation pressure low & $\begin{array}{c}\text { Patch reef } \\
\bar{x}=87.1, s=15.7, \mathrm{n}=30\end{array}$ & $\begin{array}{c}\text { Full cage } \\
\bar{x}=90.9,5=7.4, \mathrm{n}=1.2\end{array}$ \\
\hline Predation pressure high & $\begin{array}{c}\text { Continuous reef } \\
\bar{x}=68.2, s=21.0, \mathrm{n}=30\end{array}$ & $\begin{array}{c}\text { Open plot } \\
\bar{x}=69.8, s=19.5, n=12\end{array}$ \\
\hline Likely effect due to predators & Patch - Continuous $=189$ & Fill - Open $=21.1$ \\
\hline
\end{tabular}


(a) Initial abundance at hatching

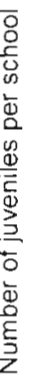

(b) Remaining abundance at $18 \mathrm{~mm} \mathrm{TL}$

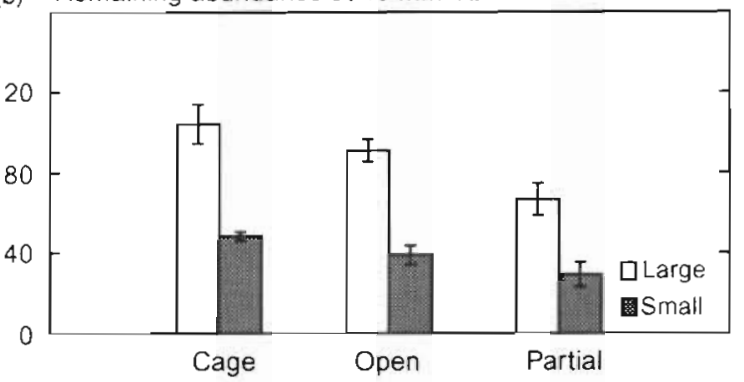

(c) Percentage survivorship

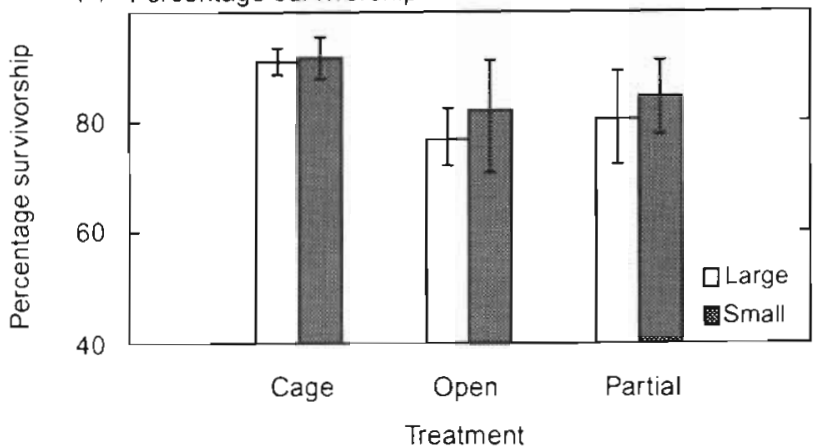

Fig. 3. Acanthochromis polyacanthus. Expt Il. Mean number ( \pm SE) of juveniles per school for large and small schools, among caging and density treatments $(n=6)$ at (a) the beginning of the experimont and (b) the end of the experiment; and (c) mean percentage survival ( \pm SE) per school at the end of the experiment

man's rank correlation coefficient $=0.86, \mathrm{n}=24, \mathrm{p}<$ 0.05 ) and absence of predators (Spearman's rank correlation coefficient $=0.97, n=12, p<0.05$ ) there is also a suggestion that predation limited the abundance of older prey (Fig. 4). In the absence of predators all schools that started with $>100$ individuals finished with $>100$ individuals, but in the presence of predators all schools that started with $>100$ individuals finished with $\leq 100$ individuals. This result is unlikely by chance alone ( $p<0.009$; Fisher's Exact Test) and suggests that predators limited the number of older fish to $\leq 100$ fish per school.

Is growth influenced by the abundance of conspecifics and predators? The maximum age at which all schools remained inside cages was $12 \mathrm{~d}$, hence the effects of density and cages on growth were calculated for $12 \mathrm{~d}$ old fish (<19 mm TL). Full cages and large schools had a positive effect on growth (Fig. 5). After $12 \mathrm{~d}$ the mean total length for juveniles was significantly higher inside full cages than in partial cages and open plots $\left(F_{2.30}=4.89, \mathrm{p}<0.05\right)$. Similarly, the mean total length reached after $12 \mathrm{~d}$ was greater for fish in large schools $\left(F_{1.30}=6.25, \mathrm{p}<0.05\right)$.

\section{DISCUSSION}

Reef fish, which predominantly have open populations, are thought to differ from organisms with closed populations because variation in input (recruitment) from planktonic larvae is considered to have disproportionate effects on population abundance (reviews: Doherty \& Williams 1988, Booth \& Brosnan 1995). The validity of this recruitment-limitation model depends on the extent to which patterns of input are modified by mortality, predation often being assumed to be the main source of mortality. Therefore, if closed populations are less affected by variable input, I predicted that predation, and not variation in input, would primarily contribute to the abundance of Acanthochromis polyacanthus (closed population).

\section{Predation influences both mortality and growth}

Predation was the major cause of mortality in Acanthochromis polyacanthus. Similar results have been

Table 3. Acanthochromis polyacanthus. Results of 2-way ANOVAs showing variation in (a) survival, (b) initial abundance, and (c) abundance of juveniles at $18 \mathrm{~mm}$ TL among treatments of Expt 11. Cochran's $C$ test, variances $=6, \mathrm{df}=5$

\begin{tabular}{|c|c|c|c|c|c|c|c|c|c|c|}
\hline \multirow[t]{2}{*}{ Source } & \multirow[t]{2}{*}{ df } & \multicolumn{3}{|c|}{ (a) $C=0.361$} & \multicolumn{3}{|c|}{ (b) $C=0.349$} & \multicolumn{3}{|c|}{ (c) $C=0.378$} \\
\hline & & MS & $F$ & $\mathrm{p}$ & MS & $F$ & $\mathrm{p}$ & MS & $F$ & $p$ \\
\hline Cages (= Cg) & 2 & 872 & 4.07 & $<0.05$ & 2909 & 10.9 & $<0.01$ & 2438 & 9.5 & $<0.01$ \\
\hline Density & 1 & 386 & 1.80 & $>0.10$ & 422849 & 160.6 & $<0.01$ & 21121 & 81.9 & $<0.01$ \\
\hline $\mathrm{Cg} \times$ Density & 2 & 37 & 0.71 & $>0.50$ & 937 & 3.5 & $<0.05$ & 280 & 1.1 & $>0.25$ \\
\hline Residual & 30 & 214 & & & 266 & & & & & \\
\hline
\end{tabular}




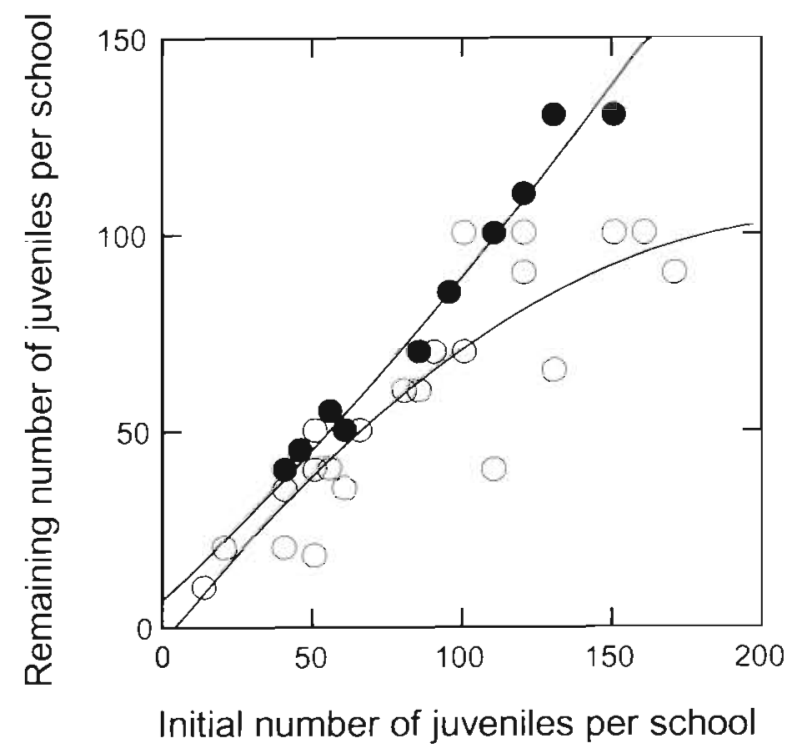

Fig. 4. Acanthochromis polyacanthus. Expt II. Relationship between the surviving number of juveniles per school and initial density among treatments with predators $10=$ open plots and partial cages, $n=24$ ) and without predators $(=$ full cages, $n=12$ ). Each point represents a school and a quadratic line has been fitted to hollow and filled points using SYGRAPH (Wilkinson 1990)

found in other experimental studies, suggesting that predation (particularly predation by large fish) can be a major cause of juvenile mortality (Shulman \& Odgen 1987. Caley 1993, Hixon \& Beets 1993, Carr \& Hixon 1995, Hixon \& Carr 1997). Despite such observations, the extent to which large predatory fish are responsible for natural mortality is often not known. Hence, a strength of the current study was the ability to compare experimental mortality to natural mortality. Here, mortality experimentally attributable to large predatory fish was similar to the difference in natural mortality between reefs with high and low densities of predators. This equivalence suggests that large predatory fish were the primary source of early juvenile mortality between locations with low and high densities of these predators.

It has been suggested the mortality of juvenile reef fish may also be strongly affected by small predatory fish (Connell 1998). Small piscivorous fish, such as Thalassoma lunare (Connell 1998), appear to contribute to the pattern of greater mortality of juvenile Acanthochromis polyacanthus on continuous than patch reef. Encounter rates of small predatory fish with schools of juvenile $A$. polyacanthus have been positively correlated with this pattern of mortality at these reefs (Connell unpubl, data). Hence, patterns of greater mortality of juvenile and adults at the perimeter of the lagoon than the centre of the lagoon (Connell
1996, Jones 1997) may be explained by a combination of small and larger predatory fish.

Variation in growth of coral reef-fish is seldom discussed in relation to regimes of predation pressure. Instead, such variation is more often linked to variation in conspecific density and/or food availability (Jones 1986, Forrester 1990, Kerrigan 1994, Booth 1995). In the current study, however, a reduction in predation pressure resulted in the increase in growth of prey, a phenomenon which has not previously been reported in coral reef-fishes. Differences in growth between different levels of predation pressure are most likely due to a lower level of harassment, facilitating uninterrupted feeding (see Sih 1997). A number of studies have established that young fish can recognise their predators (review: Stein 1979) and subsequently alter their feeding behaviour (Schmitt \& Holbrook 1985). For example, the duration (Holbrook \& Schmitt 1988) and rate (Prejs 1987) at which fish feed can alter when they are at risk of predation. The present data offer 2 important insights. First, variation in growth of prey may not always be a simple response to prey density and/or food availability; and second, if predation affects rates of growth, it may also affect rates of maturation and fecundity. Both are likely to be more closely related to size than age in fish (Jones 1991).

\section{Density-dependent predation and its effect on abundance}

Although density-independent mortality can modify patterns of recruitment (Warner \& Hughes 1988) the documentation of density-dependent mortality has been a major focus of fish ecologists. This is largely because density-dependent mortality provides a mechanism for limiting population abundance after recruitment, and evidence for the lack of densitydependent mortality has been used to infer recruitment limitation (see Doherty \& Fowler 1994). However, the usefulness of this dichotomy has been recently questioned (Steele 1997) and this doubt is well illustrated here. Mortality was weakly densitydependent in the presence of predators. Consequently, predators did not eliminate the largest peaks in abundance (large vs small schools), but variation in predation pressure did eliminate smaller peaks among large schools. Hence, patterns of abundance were set simultaneously by input and subsequent density-dependent predation. While this possibility is not a new idea (Warner \& Hughes 1988) and many studies have tested for density-dependent mortality (reviews Jones 1991, Booth \& Brosnan 1995, Caley et al. 1996), data supporting this model are few (see Steele 1997). 
(a) Among cages

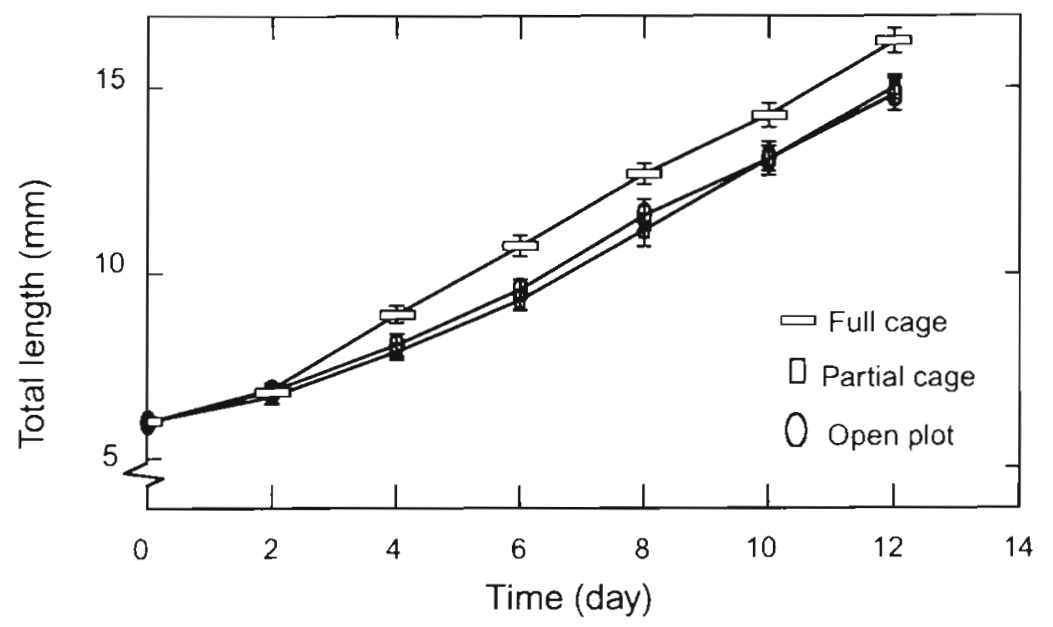

(b) Between densities

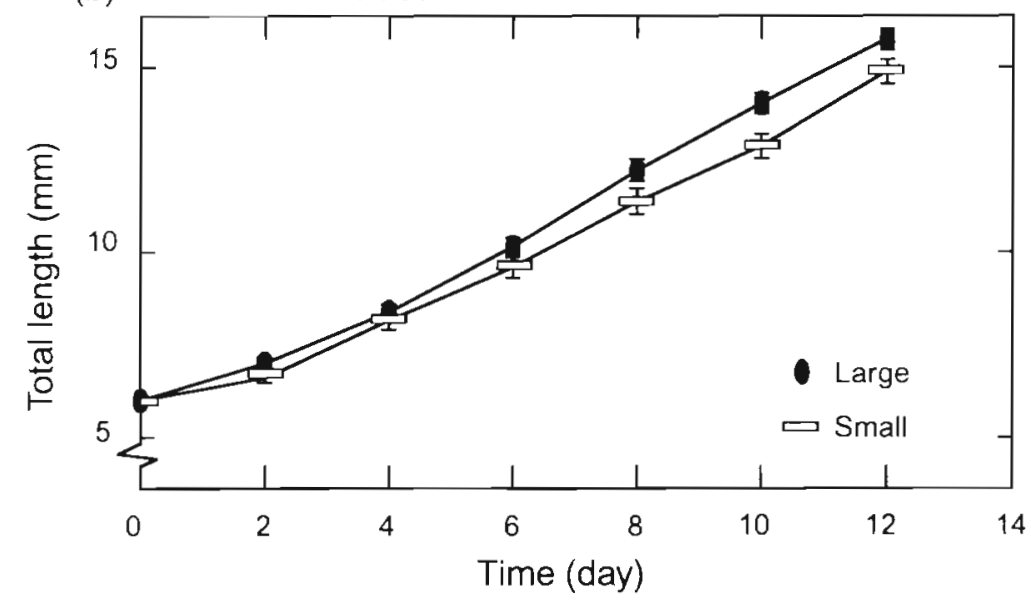

Fig. 5. Acanthochromis polyacanthus. Mean total length ( \pm SE) per school versus time for schools: (a) among caging treatments $(n=12)$ and $(b)$ between density treatments $(n=18)$

The possibility that predators are highly likely to respond differently to large aggregations of prey rather than to smaller aggregations or to isolated individuals has been recognised in other systems such as insects (e.g. Cappuccino 1991), marine invertebrates (e.g Eggleston et al. 1992) and mammals (Sinclair et al. 1990), but not so much for reef fish. Little is known about prey selection in piscivorous fish, but it seems that large predatory fish target Acanthochromis polyacanthus in larger schools. Kingsford (1992) suggested that much of the spatial and temporal variation in the diet of a large grouper could be attributed to the preference for and availability of abundant, aggregating prey. Similarly, such prey selection has been proposed to explain why abundant, schooling species suffer greater rates of mortality than solitary species from those families (Connell \& Gillanders 1997).
Solitary species are by far the most studied reef-fish (review Jones 1991), but they tend to recruit in smaller numbers and suffer smaller rates of mortality than their gregarious congeners (Connell \& Gillanders 1997). Gregarious species tend to have very high initial density, but then suffer extraordinarily high rates of mortality (e.g. Eckert 1987, Shulman \& Ogden 1987, Connell 1996) which may bound fluctuations in abundance of older fish from year to year. If predators target abundant, aggregating prey, densitydependent predation may be an important population regulator of schooling species and less important for the more commonly studied solitary species (c.f Carr \& Hixon 1995, Hixon \& Carr 1997).

\section{Conclusions}

The exclusion of large predatory fish, some of which were known to consume reef-fish and juvenile Acanthochromis polyacanthus, resulted in the enhanced growth and survivorship of juveniles. Large predatory fish, at least in some years, may be the primary source of juvenile mortality in $A$. polyacanthus between continuous and patch reef. Strong support for the reality of these experiments can be derived from the observation that the magnitude of experimental mortality related well to the magnitude of mortality occurring in the natural environment. Nonetheless, the large differences in survivorship between years illustrate the variable nature of predatory impacts over time. The results also indicated that intraspecific competition was unimportant as a factor contributing to growth, mortality and juvenile abundance. Although predation was the primary source of mortality, because it was weakly density-dependent, large fluctuations in recruitment (births) persisted and contributed importantly to fluctuation in prey density. Density-dependent processes may not only directly influence abundance through mortality, but also indirectly through growth. If early juvenile mortality is high, slower-growing individuals may be subject to higher age-specific mortality rates (see reviews: Doherty \& Williams 1988, Mapstone \& Fowler 1988). In this study, the failure to detect negative effects of density on growth indicates that density-dependence did not influence mortality through heavier predation on 
slower growing schools. In conclusion, this study supports the model that when density-dependent mortality is weak, both input and subsequent mortality will be important limiting factors. Furthermore, it questions the assumption that variation in predation and competition has greater consequences for closed populations than open populations.

Acknowledgements. This manuscript was improved by N. Andrew, M. Beck, S. Holbrook, C. Buxton, B. Gillanders, M. Kingsford, B. Menge and A. Underwood. A large number of people assisted in the field: T. Crowe, $N$. Gallahar, B. Gillanders, T. Minchinton, D. Morrisey and R. Schmitt. This research was supported by an ARC grant to $M$. J. Kingsford and a Great Barrier Marine Park Authonty Research Grant and a University of Sydney Postgraduate Research Scholarship to S.D.C.

\section{LITERATURE CITED}

Booth DJ (1995) Juvenile groups in a coral-reef damselfish density-dependent effects on individual fitness and population demography. Ecology 76:91-106

Booth DJ, Brosnan DM (1995) The role of recruitment dynamics in rocky shore and coral reef fish communities. Adv Ecol Res 26:309-385

Caley MJ (1993) Predation, recruitment and the dynamics of communities of coral-reef fishes. Mar Biol 117:33-43

Caley MJ, Carr MH, Hixon MA, Hughes TP, Jones GP, Menge BA (1996) Recruitment and the local dynamics of open marine populations. Annu Rev Ecol Syst 27:477-500

Cappuccino $N$ (1991) Density dependence in the mortality of phytophagous insects on goldenrod (Solidago altissima). Environ Entomol 20:1121-1128

Cappuccino N, Daman H, Dubuc JF (1995) Spatial behavior and temporal dynamics of outbreak and nonoutbreak species. In: Cappuccino N, Price PW (eds) Population dynamics: new approaches and synthesis. Academic Press, San Diego, p 65-82

Cappuccino N. Price PW (1995) Population dynamics: new approaches and synthesis. Academic Press, San Diego

Carr MH, Hixon MA (1995) Predation effects on early postsettlement survivorship of cordl-reef fishes. Mar Ecol Prog Ser 124:31-42

Caswell H (1978) Predator-mediated coexistence: a non-equilibrium model. Am Nat 112:127-154

Cody (1968) On the methods of resource division in grassland bird communities. Am Nat 102:107-147

Cohen $J$ (1988) Statistical power analysis for the behavioural sciences. Lawrence Erlbaum Associates, Hillsdale, NJ

Connell SD (1996) Variations in mortality of a coral reef fish: links with predator abundance. Mar Biol 126:347-352

Connell SD (1997) Exclusion of predatory fish on a coral reef: the anticipation, pre-emption and evaluation of some caging artefacts. J Exp Mar Biol Ecol 213:181-198

Connell SD (1998) Patterns of piscivory by resident predatory reef fish at One Tree Reef, Great Barrier Reef. Mar Freshwat. Res 49:25-30

Connell SD, Gillanders BM (1997) Mortality and abundance of a schooling reef fish. Proc 8th Int Coral Reef Symp 1: $1035-1038$

Connell SD, Kingsford MJ (1998) Spatial, temporal and habitat-related variation in the abundance of large predatory fish at One Tree Reef, Australia. Coral Reefs 17:49-57
Connor EF, Beck MW (1993) Density-related mortality in Cameraria hamadrvadella (Lepidoptera: Gracillariidae) at epidemic and endemic densities. Oikos 66:515-525

Doherty PJ (1991) Spatial and temporal patterns in recruitment. In: Sale PF (ed) The ecology of fishes on coral reefs. Academic Press, San Diego, p 261-293

Doherty PJ, Fowler A.J (1994) Demographic consequences of variable recruitment to coral reef fish populations: a congeneric comparison of two damselfishes. Bull Mar Sci 54 $297-313$

Doherty PJ, Sale PF (1985) Predation on juvenile coral reef fishes: an exclusion experiment. Coral Reefs 4:225-234

Doherty PJ, Willams DMcB (1988) The replenishment of coral reef fish populations. Oceanogr Mar Biol Annu Rev 26: $487-551$

Eckert GJ (1987) Estimates of adult and juvenile mortality for labrid fishes at One Tree Reef, Great Barrier Reef. Mar Biol 95:167-171

Eggleston DB, Lipcius RN, Hines AH (1992) Density-dependent predation by blue crabs upon infaunal clam species with contrasting distribution and abundance patterns. Mar Ecol Prog Ser 85:55-68

Forrester GE (1990) Factors influencing the juvenile demography of a coral reef fish. Ecology 71:1666-1681

Hixon MA. (1.991) Predation as a process structuring coral reef fish communities. In: Sale PF (ed) The ecology of fishes on coral reefs. Academic Press, San Diego, p 475-508

Hixon MA, Beets JP (1993) Predation, prey refuges, and the structure of coral-reef fish assemblages. Ecol Monogr 63: $77-101$

Hixon MA, Carr MH (1997) Synergistic predation, density dependence, and population regulation. in marine fish. Science 277:946-949

Holbrook SJ. Schmitt RJ (1988) Effects of predation risk on foraging behaviour: mechanisms altering patch choice. J Exp Mar Biol Ecol 121:151-163

Hunter AF (1995) Ecology, life history, and phylogeny of outbreak and nonoutbreak species. In: Cappuccino $N$, Price PW (eds) Population dynamics: new approaches and synthesis. Academic Press, San Diego, p 41-64

Jones GP (1986) Food availability affects growth in a coral reef fish. Oecologia 70:136-1.39

Jones GP (1987) Competitive interactions among adults and juveniles in a coral reef fish. Ecology 68:1534-1547

Jones GP (1991) Postrecruitment processes in the ecology of coral reef fish populations: a multifactorial perspective. In: Sale PF (ed) The ecology of fishes on coral reefs. Academic Press, San Diego, p 294-328

Kerrigan BA (1994) Post-settlement growth and body composition in relation to food availabulity in a juvenile tropical reef fish. Mar Ecol Prog Ser 111:7-15

Kingsford MJ (1992) Spatial and temporal variation in predation on reef fishes by coral trout (Plectropomus leopardus, Serranidae). Coral Reefs 11:193-198

Kirkpatrick M (1984) Demographic models based on size, not age, for organisms with incteterminate growth. Ecology $65: 1874-1884$

Leis JM (1994) Coral sea atoll lagoons: closed nurseries for the larvae of a few coral reef fishes. Bull Mar Sci 54: 205-227

Leis JM, Rennis DS (1983) The larvae of Indo-Pacific coral reef fishes. NSW University Press, Sydney, and University of Hawaii Press, Honolulu

MacArthur RH, Recher H, Cody M (1966) On the relation between habitat selection and species diversity. Am Nat 100:319-332

Mapstone BD, Fowler AJ (1988) Recruitment and the struc- 
ture of assemblages of fish on coral reefs. Trends Ecol Evol 21:72-77

Minchella DJ, Scott ME (1991) Parasitism: a cryptic determinant of animal community structure. Trends Ecol Evol 6 $250-254$

Murdoch WW, Walde SJ (1989) Analysis of insect population dynamics. In: Grubb PJ, Whittaker JB (eds) Towards a more exact ecology. Blackwell, Oxford, p 113-140

Nakazono A (1993) One-parent removal experiment in the brood-caring damselfish. Acanthochromis polyacanthus, with preliminary data on reproductive biology. Aust J Mar Freshwat Res 44:699-707

Olson RR (1985) The consequences of short-distance larval dispersal in a marine invertebrate. Ecology 66:30-39

Prejs A (1987) Risk of predation and feeding rate in tropical freshwater fishes: field evidence. Oecologia (Berl) 63:6-12

Scheltema RS, Williams IB (1983) Long-distance dispersal of planktonic larvae and the biogeography and evolution of some Polynesian and western Pacific mollusks. Bull Mar Sci 33:545-565

Schmale MC (1991) Prevalence and distribution patterns of tumors in bicolor damselfish (Pomacentrus partitus) on South Florida reefs. Mar Biol 109:203-212

Schmitt RJ, Holbrook SJ (1985) Patch selection by juvenile black surfperch (Embiotocidae) under variable risk: interactive influence of food quality and structural complexity. J Exp Mar Biol Ecol 79:39-64

Shulman MJ, Ogden JC (1987) What controls tropical reef fish populations: recruitment or benthic mortality? An example in the Caribbean reef fish Haemulon flavolineatum. Mar Ecol Prog Ser 39:233-242

Sih A (1997) To hide or not to hide? Refuge use in a fluctuating environment. Trends Ecol Evol 12:375-376

Sinclair ARE, Olsen PD, Redhead TD (1990) Can predators

Editorial responsibility: Tony Underwood /Contributing

Editor), Sydney, Australia regulate small mammal populations? Evidence from house mouse outbreaks. Oikos 59:382-392

Steele NA (1997) Population regulation by post-settlement mortality in two temperate reef fishes. Oecologia 112: $64-74$

Stein RA (1979) Behavioral responses of prey fish to fish predators. In: Stroud RH, Clepper $\mathrm{H}$ (eds) Predator-prey systems in fisheries management. Sport Fishing Institute, Washington, DC, p 343-353

Thresher RE (1983a) Environmental correlates of the distribution of planktivorous fishes in the One Tree Reef lagoon. Mar Ecol Prog Ser 10:137-145

Thresher RE (1983b) Habitat effects on reproductive success in the coral reef fish, Acanthochromis polyacanthus (Pomacentridae). Ecology 64:1184-1199

Thresher RE (1984) Reproduction in reef fishes. TFH Publications, Neptune City

Thresher RE (1985a) Brood-directed parental aggression and early brood loss in the coral reef fish. Acanthochromis polyacanthus (Pomacentridae). Anim Behav 33:897-907

Thresher RE (1985b) Distribution, abundance, and reproductive success in the coral reef fish, Acanthochromis polyacanthus. Ecology 66:1139-1150

Underwood AJ (1981) Techniques of analysis of variance in experimental marine biology and ecology. Oceanogr Mar Biol Annu Rev 19:513-605

Warner RR, Hughes TP (1988) The population dynamics of reef fishes. Proc 6th Int Coral Reef Symp 1:149-155

Wilkinson L (1990) SYGRAPH: The system for graphics. SYSTAT, Inc, Evanston, IL

Williams DMcB, Hatcher AI (1983) Structure of fish communities on outer slopes of inshore, mid-shelf and outer shelf reefs of the Great Barrier Reef. Mar Ecol Prog Ser 10. $239-250$

Submitted: November 18, 1997; Accepted: May 15, 1998

Proofs received from author(s): July 13,1998 